\title{
The Madrasa in Indonesia \\ (Authority, Knowledge and Discourse Surrounding its Development)
}

\author{
Syamsul Kurniawan \\ Institut Agama Islam Negeri Pontianak, Pontianak, Indonesia \\ syamsulkurniawan001@gmail.com \\ Muhammad Miftah \\ Institut Agama Islam Negeri Kudus, Kudus, Indonesia \\ muhammadmiftah@stainkudus.ac.id
}

\begin{abstract}
The focus of this paper is the madrasa in Indonesia and its development which is examined from the perspective of Michel Foucault regarding their authority, knowledge and discourse. The madrasa's performance, which is still relatively low and unable to compete with public schools or pesantrens (Islamic Boarding Schools), will be examined from this perspective. This paper departs from the study of literature with a historical-sociological approach. The sources of the data come from the literature related to the history and development of madrasas. From Foucoult's perspective, the performance of the madrasa--which in its development shows a decline trend and is of relatively low quality and less competitive compared with general schools or pesantrens-- is closely related to power, knowledge and discourse factors. My argument is supported by the evidence that there is no an established "blueprint" for the supervision and development of madrasas in Indonesia, in contrast to schools or pesantrens. Likewise, the problem of interplay of madrasa policies in the integration of the national education system has put the madrasa in the midst of domination of schools and pesantrens, especially in the midst of society since the appreciation and level of community participation in the madrasa are not very encouraging. In addition, there is an opinion among the public which perceives the madrasa as the second educational institution after schools or pesantrens. This opinion is, of course, supported by empirical data, such as research from Nur Hamzah (2017) and Sukino (2017) which examined the madrasas in West Kalimantan Province, and revealed the poor quality of some madrasas in this area, which in my opinion is the "top of the iceberg" of the madrasa, especially in the outermost, interior and underdeveloped areas of Indonesia.
\end{abstract}

Keywords: Madrasa; power; knowledge; discourse 


\begin{abstract}
Abstrak
Fokus tulisan ini adalah madrasah di Indonesia dan perkembangannya yang dikaji dari perspektif Michel Foucault tentang kuasa, pengetahuan dan wacana. Performa madrasah yang sampai pada saat ini masih relatif rendah dan kalah bersaing dengan sekolah umum atau pesantren, penulis coba identifikasi dari perspektif ini. Tulisan ini berangkat dari kajian kepustakaan dengan pendekatan historis-sosiologis, yang sumber datanya berasal dari literatur-literatur yang berkaitan dengan sejarah dan perkembangan madrasa. Dari perspektif Foucault, bahwa performa madrasah yang dalam perkembangannya menunjukkan tren kemunduran, kualitasnya relatif rendah dan kalah bersaing dengan sekolah umum atau pesantren, sangat berhubungan dengan faktor kuasa, pengetahuan dan wacana. Argumen penulis dikuatkan dengan bukti-bukti tentang belum adanya "cetak biru" pembinaan dan pengembangan madrasah di Indonesia yang sudah mapan, berbanding terbalik dengan sekolah atau pesantren. Begitupula, terjadinya problem interply (tarik ulur) kebijakan madrasa dalam integrasi sistem pendidikan nasional membuat madrasa berada di tengahtengah dominasi sekolah dan pesantren. Apalagi di tengah-tengah masyarakat, apresiasi dan tingkat partisipasi masyarakat terhadap madrasa kurang menggembirakan. Termasuk adanya opini di tengah-tengah masyarakat, yang mempersepsikan madrasah sebagai lembaga pendidikan nomor dua setelah sekolah atau pesantren. Tentu saja opini ini didukung dengan data-data empiris. Seperti penelitian Nur Hamzah (2017) dan Sukino (2017) yang meneliti madrasahmadrasah yang ada di Provinsi Kalimantan Barat, dan mengungkap betapa buruknya kualitas sebagian madrasah di daerah ini, yang hemat penulis merupakan "puncak gunung es" dari madrasah-madrasah terutama di kawasan-kawasan terluar, terdalam dan tertinggal dari Indonesia.
\end{abstract}

Kata Kunci: Madrasah; kuasa; pengetahuan; wacana

\title{
A. Introduction
}

Madrasas have long historical roots, marked by the emergence of the Madrasa Nizamiyyah in Baghdad.(Agus Salim, 2015, p. 63) In the beginning, Islamic educational institutions were informal in the form of Islamic da'wah, then developed into the form of halaqah, until they finally evolved into the form of formal educational institutions such as madrasas. Apart from that, the library was also developed, which was originally established in connection with the translation effort as was done in the Bayt al-Hikmah academy. Islamic attention to education and the glory of books is a factor underlying the development of libraries in the Islamic world which is functionally synergized with madrasas as educational institutions.(Mehdi Nakosteen, 1964) 
Understandably, the development of madrasa is in line with efforts to formalize Islamic education, when connected with the interests of a particular government system. It is at this stage that madrassas as Islamic educational institutions progressively experience significant developments, besides the library, because there is an element of guidance from the ruling government.(Agus Salim, 2015, 64) In the history of Islamic education, Nizâm al-Mulk was known as a pioneer of the foundation of madrasa for the first time as an educational institution for Muslims, namely the Madrasa Nizamiyah of Baghdad. Ahmad Syalabi, Mehdi Nakosteen and Michael Stanton argued that the madrasa founded by Nizâm Al-Mulk was a new type of school in the previous era that did not exist, so that its existence was widely-known and became a blueprint for the development of similar madrassas in the Islamic world.(Ahmad Syalabi, 1973; Nakosteen, 1964, 38-40; Stanton, 1990)

In fact, it is no exaggeration to assume the existence of the Nizâmiyyah Madrasa as irreplaceable in the ideal model of madrasa throughout the history of madrasa development until today. According to Ibn al-Jawzi's records, the Nizâmiyyah Madrasa began to be constructed in $457 \mathrm{AD}$./1065 AH by tearing down the old palace building on the bank of the Tigris River and taking the building materials for the construction of the madrasa. It was confirmed that the madrasa was located east of Tigris. Mahmud Yunus added that the madrasa was built alongside the Dijlah River, in the middle of the Salasah market.(H. Mahmud Yunus, 1986, 72)

Linguistically, the term 'madrasa' comes from Arabic which can be interpreted as a "place of learning", and can also be associated with "school". However, in our national education system, the two are distinguished. The school is known as an elementary and secondary level educational institution whose curriculum focuses on general subjects, and its management is under the auspices of the Ministry of Education and Culture. Meanwhile the madrasa is known as primary and secondary religious educational institutions, under the Ministry of Religious Affairs. There are more than one form of madrasa. As understood, in the history of madrasa development in Indonesia, there are two types of madrasas, madrasa diniyah and non-diniyah madrasa. Madrasa diniyah is a religious educational institution whose curriculum is similar to pesantren, emphasizing religious material, while non-diniyah madrasa is a religious educational institution whose curriculum, in addition to religious material, provides general subjects with a balanced percentage.(Muhammad Kosim, 2017, 42) As an illustration, look at figure 1 below: 


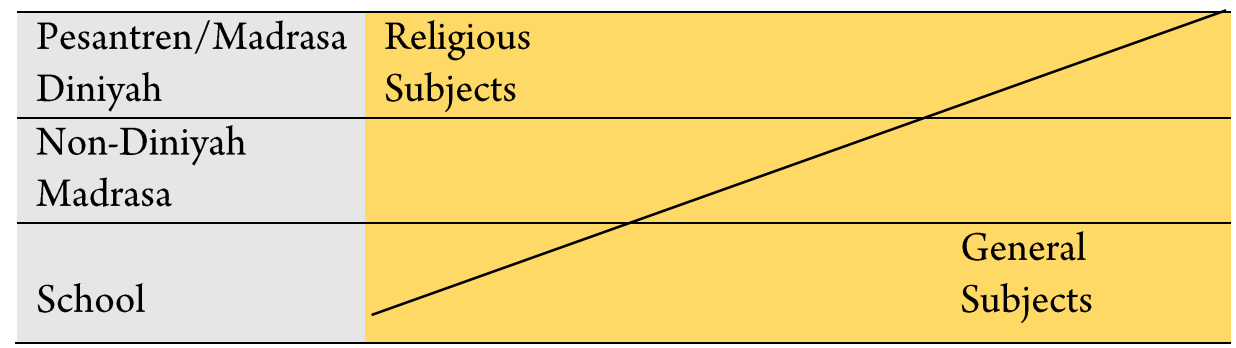

Figure 1. The portion of Religious and General Subjects at the Pesantren, Madrasa and Schools.

The growth and development of madrasa in Indonesia in its history is a result of the progressive response to the pesantren which at that time avoided modernization. (Syamsul Kurniawan, 2017, 1-2, 2018, 221-222) Mahmud Yunus and Karel A. Steenbrink for example, who in his book assumes madrasa as a further development or reform of pesantren educational institutions.(Mahmud Yunus, 1979; Karel A. Steenbrink, 1994) But in its course, the development of madrasa actually experienced less positive trends and seemed unable to compete with public schools (in the mastery of general knowledge) and with pesantren (in the mastery of religious knowledge).(Jamal Makmur Asmani, 2013, 105) Even so, public interest in madrasas does not mean there are none. In a number of cases of excellent madrasas, which are not many, the interest of some parents to send their children to these madrasas is quite high.(Abuddin Nata, 2012, 317)

Referring to the positive trends in the development of Madrasa Nizâmiyyah in Baghdad, which were clearly very much determined by the knowledge, power and discourse that developed at that time, and from my point of view, the trends also occurred in the development of madrasas in Indonesia. The development of madrasas in Indonesia in this context is also certainly related to the power, knowledge, and discourse that surrounds it. The knowledge that is different from discourse, in the view of Michel Foucault is a reduction of structured discourse. This discourse is in our minds and subtly becomes our paradigm in thinking and acting. The discourse of life, as part of ourselves, regulates our behavior and limits our movements.(Michel Foucault, 1976, 74) This discourse was later referred to as Foucault's potential to become truth. The truth according to him is the dominant discourse in a society's structure. Discourse and knowledge in practice are often used to preserve power. Power itself is an institutional network that dominates and is related to other relations, which play the role of conditioning or being conditioned. (Michel Foucault, 1980, 142) 
There have been quite a lot of studies on madrasas in Indonesia, only to the extent that literature searches have not touched on the aspects of knowledge, power and discourse surrounding the development trends compared to this paper, such as the studies conducted by Muzhoffar Akhwan (2008), Agus Salim (2015), Ibnu Rusydi (2014), Weti Susanti (2017), Nur Hamzah (2017), Sukino (2017), Hamruni \& Syamsul Kurniawan (2018) and Syamsul Kurniawan (2019) who did research on the construction and development of the madrasa along with its prospects and challenges. In addition, other studies conducted by Tabrani ZA. (2013), Moh. Arif (2013), Ainurrofiq Dawam \& Ahmad Ta'arifin (2005) focused on aspects of management. The focus of this paper is on the trends in the development of the madrassa in Indonesia, which is strongly influenced by factors of power, knowledge, and discourse surrounding it. So that the problem to be discussed in this article is how power, knowledge and discourse factors contribute to the decline of the madrasa in Indonesia. This research is a literature study with a historical-sociological approach with the source of data coming from the literature related to the history and development of madrasas.

\section{B. Discussion}

\section{The Madrasa in Indonesia and the Traces of its Development}

The discussion on the development of the madrasa in Indonesia below follows a historical periodization based on the classification made by Ainurrafiq Dawam and Ahmad Ta'arifin, namely the early 20th century, the Old Order era, the New Order era, and the reform era until today.(Ainurrofiq Dawam \& Ahmad Ta'arifin, 2005)

\section{The madrasa in the Early 20th Century}

In Indonesia, the development of education and instruction in the form of madrasa which had emerged in the early 20th century, was a progressive development of the traditional system (pesantren), triggered by the Dutch Hindi state policies that discriminated against pesantren educational institutions, as well as the emergence of Islamic reform movements in Indonesia which had quite intensive contact with progressive movements in the Middle East. (Maksum, 1999, 82,97; Supani, 2009, 5)

In this period, several madrasas had allegedly been established, such as the madrasa built by R. Hadipati Sosrodiningrat in Solo called Madrasa Mambaul Ulum around 1905, Madrasa al-Jamiatul Khairiyah established around 1906, Madrasa Thawalib in West Sumatra pioneered by Shaykh Abdul Karim Amrullah in 1907, Madrasa Adabiyah pioneered by Abdullah Ahmad in 1909, and Madrasa Diniyah pioneered Zaenuddin Labay 1916, as well as 
Madrasa Muallimin Muhammadiyah established by KH. Ahmad Dahlan in 1918 in Yogyakarta (Karel A. Steenbrink, 1994, 44-62; Maksum, 1999, 99-111)

The madrasas that were established and developed in this period, as mentioned above, can be assumed to be the prototypes of today's madrasas (Ainurrofiq Dawam \& Ahmad Ta'arifin, 2005, 42). It is called so because in its development, the madrasa models in Indonesia will not lose their basic format. There are at least four basic formats here: first, a model that imitates Dutch-made schools, such as the teaching system that takes place in the classroom, although from the material aspect there is no change with the emphasis, especially in the religious sciences, such as the Madrasa Thawalib which was pioneered by Syaikh Abdul Karim Amrullah in 1907. Second, a model that emphasizes more on religious material with a limited inclusion of material from general sciences. An example of this model is the Madrasa Diniyah which was pioneered by Zaenuddin Labai in 1916 in West Sumatra. Third, a model that integrates in a balanced way between religious material and material from general sciences, such as the Madrasa Muallimin Muhammadiyah pioneered by KH. Ahmad Dahlan in 1918 in Yogyakarta; and fourth, a model that follows the gubernemen (Dutch Colonial Government) pattern with the addition of several religious subjects, such as the Madrasa Adabiyah pioneered by Abdullah Ahmad in 1909 in West Sumatra and the Madrasa Muallimin Muhammadiyah pioneered by KH. Ahmad Dahlan in 1918 in Yogyakarta. Thus, in this fourth model, the portion of material from general sciences in the madrasa is slightly more than the three models of madrasa mentioned earlier. (Muhaimin, 2003)

\section{The Madrasa in the Old Order Era}

In the period after Indonesia's independence, the state's attention to religious education was already there. However, the focus of the attention was quite insignificant. In the Old Order era, both public and private schools received assistance for their operations from the State. This is in line with the recommendation of the Central National Committee Working Body (BPKNP) on December 27, 1945. Religious education in the Old Order era was specifically regulated through Law No. 4 of 1950 in chapter XII Article 20, which regulates: first, at school. - State schools teach religious lessons, and the parents of students make decisions whether or not their children will attend these lessons; second, the way of administering religious education in state schools is regulated in a regulation stipulated by the Minister of Education and Culture Education, together with the Minister of Religious Affairs.

In the Old Order era, the development of madrasas was closely related to the work of the Department of Religious Affairs, which was officially formed on January 3, 1946. 
Understandably the orientation of the Department of Religious Affairs in the field of education, in addition to developing madrasas, is that religious education is also taught in public schools. At that time, Islamic religious education materials could be taught in public schools. Based on a document, the duties of the Education Section within the Department of Religious Affairs include: first, providing religious instruction in public and private schools; second, providing general knowledge in the madrasa; and third, providing religious teacher education (PGA) and Islamic Judge Education (PHI). Although the development of the madrasa was not encouraging at this time, in this era the Department of Religious Affairs had shown good faith in making a serious effort in the implementation of Islamic education so that in time it could get its proper place in the national education system in Indonesia. (Ainurrofiq Dawam \& Ahmad Ta'arifin, 2005, p. 43)

At least, the development of the madrasa in the Old Order era made an important contribution to the development of the madrasa in the next era. There were 24 Religious Teacher Education schools (PGA) in 1951, and in 1954 the number reached 30 units. With this data, the number of Islamic religious education teachers available at the time was quite possible to support the establishment and development of madrasa education in Indonesia. Until the mid-1960s, the number of low-level madrasas (Ibtidaiyah) reached 13,057, the number of first-level madrasas (Tsanawiyah) reached 776, and the number of upper-level madrasas (Aliyah) was estimated at 16. Thus the total number of madrasas as a whole at that time reached 13,849.(Ainurrofiq Dawam \& Ahmad Ta'arifin, 2005, 45-46)

\section{The Madrasa in the New Order Era}

In the early days of the New Order government, madrasa development basically only continued and strengthened state policies in the Old Order era. In this era madrasas were still not considered part of the national education system, but became autonomous institutions under the supervision of the Minister of Religious Affairs. The first form of fostering of madrassas after Indonesia's independence was as stipulated in the Minister of Religious Affairs Regulation No. 1 of 1946, dated 19 December 1946, concerning the provision of madrasa assistance.

With reference to the Regulation of the Minister of Religious Affairs Number 1 of 1946, that the madrasa as a place for education that teach Islamic religious knowledge as the main instruction (see explanation of article I of the regulation) received operational assistance. This operational assistance was given annually and was only limited to a few Districts in the Special Region of Yogyakarta, Jakarta and Surakarta. Thus, not all madrasa in Indonesia 
received this operational assistance for development. For madrasas in several Districts in the Special Region of Yogyakarta, Jakarta and Surakarta, the form of assistance they received was in the form of money that could only be used for the following purposes: first, giving allowances to teachers who taught at the madrasa; second, purchasing learning tools that support teaching-learning activities in the madrasa; third, renting and / or maintaining madrasa classrooms and buildings so as to get the best use of the financial assistance; and fourth, financing administration. The regulation also stipulates that in the madrasa, general sciences should also be taught at least: first, the Indonesian language, arithmetic, reading and writing in Latin script in low-level madrasas; second, with the addition of geology, history, the health of plants and nature in advanced madrasas. The number of teaching hours for general sciences is at least $1 / 3$ of the total teaching hours.(Muhammad Kosim, 2017, 47-48)

The provisions for teaching general subjects $1 / 3$ of all teaching hours were motivated by the advice of the Teaching Investigation Committee which observed that in madrassas they were rarely taught general knowledge which is very useful for daily life. Lack of general knowledge could trigger people to have incorrect opinions and narrow minds. According to this regulation, the level of education in madrassas is organized into: first, Low-Level Madrasas, with a length of study of at least 4 years for students aged 6 to 15 years; and second, Secondary Madrasas with at least 3 years of study after graduating from Low Level Madrasas for students aged 11 years and above. This regulation was later amended by Minister of Religious Affairs Regulation No. 7 of 1952 which applies to all parts of the Republic of Indonesia. In the Regulation, it is stated that the level of madrasa education is: first, Low-lever Madrasas (now known as Madrasa Ibtidaiyah) with a period of 6 years of study; second, First-Level Secondary Madrasa (now Madrasa Tsanawiyah) with a length of study of 3 years after graduating Madrasa Ibtidaiyah; and third, Upper-level Madrasa (now Madrasa Aliyah) with a length of study of 3 years after graduating from Madrasa Tsanawiyah.(Muhammad Kosim, 2017, 48)

The state Madrasa Ibtidaiyah mostly originated from madrassas that were managed by the Regional Governments of Aceh, Lampung and Surakarta.(Husni Rahim, 2005, 161-162) Since 1946 there have been 205 Islamic Low Schools that have been managed by the Regional Government of Aceh, with the Minister of Religious Affairs Decree No. I in 1959, management and maintenance was handed over to the Ministry of Religious Affairs and its name was changed to the Islamic People's School (SRI). Then through the Decree of the Minister of Religious Affairs No.104 of 1962 the name was changed to Madrasa Ibtidaiyah Negeri (MIN). The same thing happened in Lampung Regency. A total of 19 SRIs were founded based on Minister of Religious Decree No. 2 in 1959. In the regency of Surakarta as many as 11 SRIs 
with the Minister of Religious Affairs Decree No. 12 of 1959. Since 1967 there has been an opportunity to change the status of private madrassas into public madrasas based on Minister of Religion Decree No. 80 in 1967. The opportunity for status change was then terminated in 1970 based on the Decree of the Minister of Religious Affairs No. 813 of 1970, when the number of State Primary Madrasa (MIN) had reached 358 units.

The First-Level Madrasas, like Primary Madrasas, are also mostly private. The Public First-Level Madrasas were only established in 1967. The change of status, from private into public, was originally intended as a model for private madrasas. Until 1970, the Madrasa Tsanawiyah Negeri (State Madrasa Tsanawiyah --abbreviated to M.Ts.A.I.N) had reached 182 and spread throughout Indonesia. After restructuring and relocation based on Minister of Religious Affairs Decree no. 15, 16 and 17 of 1978, the abbreviation of Madrasa Tsanawiyah Negeri was changed from M.Ts.A.I.N to MTsN and their number reached 470.

The Madrasa Aliyah Negeri (State Upper-Level Madarasa) was first established through a process of status change from private into public as was the case with the Madrasa Tsanawiyah Negeri based on Minister of Religious Affairs Decree No. 80 of 1967. In the decree it is stated that the status change of the Madrasa Aliyah Al-Islam Surakarta, the Madrasa Aliyah in East Java, and the Madrasa Aliyah Palangki in West Sumatra. The status-change process continued until the issuance of the Minister of Religious Affairs Decree No. 213 of 1970 which regulates the termination of the status-change of private madrasas and the establishment of state schools / madrasas within the Ministry of Religious Affairs. Until 1970, there were 43 units of Madrasa Aliyah Negeri. The abbreviation of Madrasa Aliyah Negeri at first M.A.A.I.N was later changed to MAN based on Minister of Religious Affairs Decree no. 15, 16 and 17 of 1978.

Through the Presidential Decree Number 34 of 1972 and the Presidential Instruction Number 15 of 1974, the government adopted more operational policies in relation to madrasas. In 1975 a Joint Decree of the Three Ministers was issued regarding Education Quality in Education and the Madrasa. In the Joint Decree, Ministry of Religious Affairs, Ministry of Education and Culture and the Ministry of Home Affairs assume responsibility in fostering and developing madrasa education. In fact, the birth of the Three Ministerial Decree was partly to overcome the concern of the Muslim community that the madrasa education system would be abolished as a consequence of Presidential Decree No. 34 of 1972 and Presidential Instruction No. 15 of 1974. The issuance of the Joint Decree was based on the results of a limited Cabinet meeting on November 26, 1974. In the cabinet meeting, the Indonesian Minister of Religious Affairs, Mukti Ali, conveyed the concern of Muslims 
regarding the content and further implications of the Presidential Decree and the Presidential Instruction above. The government apparently paid attention to the problem, so the President issued instructions on the implementation of Presidential Decree No. 34 of 1972 and Presidential Instruction No. 15 of 1974 whose contents are: first, the development of general education is the responsibility of the Minister of Education and Culture, while the responsibility of religious education is the responsibility of the Minister of Religious Affairs; second, for the implementation of Presidential Decree No. 34 of 1972 and Presidential Instruction No. 15 of 1974 a collaboration was established between the Department of Education and Culture, the Department of Home Affairs and the Department of Religious Affairs.(Maksum, 1999, 149)

Furthermore, with the instructions for the implementation, the tension between religious education and national education was slightly resolved. The implementation instructions contain quite basic differences from the Presidential Decree and the Presidential Instruction, where it is stated clearly that the rights and responsibilities of managing religious education remain with the Department of Religious Affairs. Thus, the Technical Guidelines have provided a model of solutions which on the one hand provides recognition of the existence of the madrasa, and affirmation that its management remains in the hands of the Ministry of Religious Affairs, but on the other hand it still provides certainty of the continuation of efforts that lead to the formation of an integrated national education system.

As a follow up, the technical guidelines were immediately followed by the drafting of the Joint Decree of Three Ministers. In Chapter I, article 1, paragraph 2, it is stated that what is meant by Madrasa includes Madrasa Ibtidaiyah (equivalent to Elementary Schools), Madrasa Tsanawiyah (equivalent to Junior High Schools), and Madrasa Aliyah (equivalent to Senior High Schools). Furthermore, in Chapter II article 2 it is mentioned: first, a madrasa diploma is equal to a public school diploma of the same level; secondly, madrasa graduates can go to public schools at a higher level; third, madrasa students can move to public schools at the same level. While regarding management and guidance, it is stated in Chapter IV article 4 as follows: first, madrasa management is carried out by the Minister of Religious Affiars; second, fostering religious subjects in madrassas is carried out by the Minister of Religious Affairs; third, guidance and supervision of the quality of general subjects in Madrasas is carried out by the Minister of Education and Culture, together with the Minister of Religious Affairs and the Minister of Home Affairs.(Maksum, 1999, 150-151)

The Joint Decree of the Three Ministers is considered by many to be a more concrete recognition of the existence of the madrasa, and at the same time they are seen as a strategic 
step to be totally recognized and integrated into the complete National Education System. It is true that with the Joint Decree of the Three Ministers, the madrasas in Indonesia are more appreciated because they have a clearer definition, namely as educational institutions which in this context should be equivalent to public schools; although their management is still under the power of the Ministry of Religious Affairs. With reference to the Joint Decree of the Three Ministers, in terms of organization, the madrasa is identical to public schools, which in terms of education level "MI, MTs and MA" are equivalent to "SD, SMP and SMA" of public schools. As for the content of subjects taught in the madrasa, students also learn the subjects taught in public schools, such as social sciences, history, anthropology, geography, arts, languages (Indonesian and English), physics, chemistry, mathematics, etc.

Nevertheless, the state policy in the era of the New Order government as outlined in the Joint Decree of the Three Ministers apparently drew a lot of criticism, because the Joint Decree of the Three Ministers was deemed to cause madrasa students to have incomplete mastery of religious and general knowledge which will result in scarcity of Muslim clerics. So, there was a commonly-held opinion among the public which assumed that the quality of madrasa students was inferior to that of the pesantren students in the context of mastery of the religious sciences, and inferior to public school students in the context of mastery of general sciences. To find a solution, the Department of Religious Affairs in 1987, during the term of Minister Munawir Sjadzali, carried out an experimental project by building the Madrasa Aliyah Special Program (MPAK/MAK). The Department of Religious at the time hoped that this madrasa could become an educational institution capable of preparing prospective scholars who understood religion well as well as general knowledge, and mastered foreign languages (at least Arabic and English) (Husni Rahim, 2005, p. 16). However, the project failed as this MPAK/MAK did not have a legal umbrella because the madrasa outlined under the Joint Decree of the Three Ministers consisted of $70 \%$ general lessons and 30\% religious lessons. In fact, MAPK / MAK had no clear position in the Law concerning the National Education System Number 2 of 1989. The power relation factor is clearly very influential in this case.

\section{The Madrasa in the Reform Era until Today}

One of the remarkable changes of the reform is the change in the structure of the state, especially in terms of the government system, which was previously centralized to decentralize. The indicator is Law of the Republic of Indonesia Number 22 Year 1999 regarding Loca Governments. Especially in Article 7 paragraph (1) of Law of Republic of Indonesia Number 22 of 1999 which states that religion is one of the affairs not to be handle by local governments. Meanwhile, according to Article 11 paragraph (2) of Law of the Republic of Indonesia 
Number 22 of 1999, there is a provision that states that education is a mandatory affair which falls under the authority of local governments. Thus, according to this law, the matters of madrasa development should be under the authority of the local government, so that various unfair policies between madrasa and school educational institutions can be minimized.

Through Law Number 20 of 2003 concerning the National Education System, the Government has actually shown good intentions to strengthen the position of the madrasa in the national education system. This is evidenced in each article that stipulates the word school is followed by the word madrasa. As in Article 56 paragraphs 1 and 3 of Law No. 20 of 2003 concerning the National Education System, which states: first, the community has a role in improving the quality of education services which includes planning, supervision and evaluation of education programs through the education board and school/ madrasa committee; secondly, the school/ madrasa committee as an independent institution shall be formed and play a role in improving the quality of services by giving consideration, direction and support of personnel, facilities and infrastructure, and supervision of education at the level of the education unit. (Republic of Indonesia Law Number 20 of 2003 concerning the National Education System., 2003)

In addition, the state also equalizes madrassas with other schools regarding the levels and types of education, as stipulated in Law Number 20 of 2003 concerning the National Education System, namely in Article 17 paragraph 2 which states, "Basic education in the form of Elementary Schools (SD) and Madrasa Ibtidaiyah (MI) or other forms of equivalent and Junior High Schools (SMP) and Madrasa Tsanawiyah (MTs), or other forms of equivalent", and Article 18 paragraph 3 which states, "Secondary education in the form of High Schools (SMA), Madrasa Aliyah (MA), Vocational High Schools (SMK) and Vocational Madrasa Aliyah (MAK) or other equivalent forms". (Republic of Indonesia Law Number 20 of 2003 concerning the National Education System., 2003)

The enactment of Law No. 20 of 2003 concerning the National Education System has strengthened the position of the madrasa in the national education system. It is increasingly recognized and has a role in improving the quality of the nation's generation. This means that the management, quality, curriculum, recruitment of personnel, etc., including the implementation of national education also applies to the development of Islamic education in Indonesia. Obviously, the integration of Islamic education as a sub-system of national education requires various adjustments in a positive sense.(M. Daud Yahya, 2014, 83) At the very least, the country's attention to the growth and development of madrasas is expected to be better than before.(Ara Hidayat \& Imam Machali, 2012) After being reinforced by Law No. 22 
of 1999 concerning Regional Autonomy, this regulation has opened wider opportunities for madrasa development.(Mukminin Gaffar, 2012)

The existence of regulations that should be beneficial for the development of the madrasa in the country is apparently "far beyond the expectation". Although there have been breakthroughs in the development of madrasa education in Indonesia, there are still many madrasas that find it difficult to compete with pesantrens and public schools. In the context of religious sciences, the madrasa "in the public eye" finds it difficult to compete with pesantrens, and in the context of general sciences the madrasa also finds it difficult to compete with public schools.

\section{Power, Knowledge, and Discourse around the Decreasing Trend of Madrasa Development in Indonesia}

In Indonesia, the madrasa emerged from progressive ideas that responded to pesantren attitudes that avoided modernization.(Syamsul Kurniawan, 2017, 1-2, 2018, 221-222) However, in its development, the madrasa actually experienced a setback trend. Masyhuri and Taufik Dahlan, for example, assume that in terms of number, the madrasa in Indonesia is developing very rapidly, but in terms of quality, madrasa achievements are still very alarming. Masyhuri and Taufik Dahlan compared with other formal schools, which according to them, in academic achievements of general subjects, for example, madrasas were not equal to other formal schools.(Masyhuri dan Taufiq Dahlan, 2006, 1) In fact, as revealed by Asmani, that numerous opinions have emerged in the community that the madrasa in Indonesia is a less qualified educational institution. (Jamal Makmur Asmani, 2013, 105; Ki Supriyoko, 2004; Sukino, 2017, 25-26) Obviously, this is not merely an opinion, because based on empirical research conducted by Nur Hamzah (2017: 105-112) and Sukino (2017:25) the madrasas in the outermost, interior and underdeveloped regions of Indonesia are of poor quality. In the interior of Kubu Raya Regency of West Kalimantan Province, for example, there are still many madrasas that have yet to be fully accredited, coupled with inadequate conditions of facilities and infrastructure, and teachers with low educational qualifications, and the quality of education is low, which is contrary to that of schools and pesantrens. In my opinion, what is empirically revealed in Nur Hamzah and Sukino's research is only the "tip of the iceberg" of the condition of most of our madrasas today.

However, it does not indicate a lack of the state's concern. In connection with this, the State has even designed the implementation of madrasa education in each type and field of education as follows: first, basic education, which includes MI (Primary Madrasa) and MTs 
(Secondary Madrasa), emphasizes the general competencies needed for community and state life. The subjects in elementary level education in this madrasa focus more on providing functional life skills in various fields: social, cultural, economic, and based on the values of the teachings of the Islamic religion. In line with the increasingly complex challenges of life, basic education in Indonesia requires nine years to complete. The assumption is that if this minimum education is not achieved, a person will have difficulty in following developments around him. Second, secondary education, i.e. the MA, has the main goal of preparing students to be able to continue their education at the tertiary level.(Kementerian Agama, 2005, 19)

Some basic principles that become a reference in the development of the madrassa include: First, building the principle of equality between the madrasa education sector and the education sector outside the madrasa, and with other sectors. The presence of the madrasa education system must always be interpreted as a necessity to work together with other systems to realize the ideals of society. Second, the principle of educational planning. Madrasa education is progressive, not resistant to change, but able to control the direction of change. Third, the reconstructionist principle. In the condition of a society that requires fundamental change, it also means large-scale changes based on great ideas, then madrasa education must also be able to prepare ne much-needed graduates. Fourth, the principle of education which is oriented towards students. In providing educational services the characteristics of students that are general or specific must be taken into consideration. Fifth, the principle of multicultural education. The madrasa education system must understand that the community it serves is plural, and therefore pluralism needs to be a reference that is no less important than other references. Sixth, the principle of global education. Madrasa education must be able to play a role in preparing students in the constellation of global society(Kementerian Agama, 2005, 21-23)

However, what is mandated by the law related to education development policies is still not optimal. Madrasa development policies have not met the expectations and ideals of the nation, especially Muslims. There are still many madrassas in Indonesia that are still of poor quality.(Nur Hamzah, 2017) The facts show that in remote areas there are still many madrassas with dirt floors and palm leaf roofs.(Novita Intan, 2018)

The enactment of Regulation Number 20 of 2003 concerning the National Education System, which is expected to strengthen the position of madrassas in the national education system, is not entirely correct. The emergence of a policy on the decentralization of education resulting from the implication of the enactment of Law Number 22 of 1999 concerning Regional Government, Government Regulation Number 25 of 2000 concerning government 
authority and provincial authority as an autonomous region, is a breath of fresh air for madrasa education because the policy means returning the madrasa to its habitus, but is also unfortunately not yet fully successful.(Mukminin Gaffar, 2012, 133) This tendency can be seen from the fact that the achievements of most madrasa students in the field of religious sciences are still far behind compared to Islamic boarding school students, and similarly in the general sciences, they cannot compete with students from public schools.(Suyatno, 2012, 125) Again, the progressive side of madrasa education is questionable.

In general, madrassas in Indonesia are often unable to compete with pesantrens in terms of mastery of the religious sciences, and with public schools in terms of mastering general sciences. From the National Examination score data, for example, for three consecutive years, namely 2015-2017, madrasas in general are still less competitive with public schools.(Kementerian Pendidikan dan Kebudayaan, 2018)

In this case, the development of madrasas is clearly very much determined by what Michel Foucault calls power, knowledge and discourse.(Michel Foucault, 1976, 1980) This is relevant to what is explained in the previous section in the discussion section on the development of madrasas in Indonesia. In the previous discussion section, it can be seen how power, knowledge, and discourse affect the regulations issued with regard to madrasas. Knowledge, power and discourse in turn determine people's perceptions and interest in madrasas.

It must be understood, Foucault's theory of power is not the same as other previous theories on power. Foucault's theory of power views that power does not belong solely to kings, rulers or the state. But it is carried out with a series of complicated regulations that influence each other. Power occupies strategic positions related to one another. Foucault rejects the views of Marxists who view power as something that is subjective, which considers a person or group to have control over some people or a group of others. Foucault argues that the power produces reality, scope, objects, and rites of truth. Power goes through normalization and regulation. Normalization is produced by creating a structured and systematic control system with regulations.(K. Bertens, 2001, 318-319)

Power according to the Foucault's theory is run through a set of specific regulatory mechanisms that influence each other.(Michel Foucault, 1980, 141) According to him, power does not always come from outside, but also from within. Such power is often even successful in carrying out its role through a series of regulatory mechanisms and certain systems so as to produce a kind of power chain. Furthermore, Foucault explained about the relationship 
between power and knowledge. According to him, power and knowledge have a very close and inseparable relationship. Power produces knowledge, whereas knowledge has power. The power described by Foucault is not a power to physically control people and be a dictator. Power in the Foucault's definition is disguised, hidden and/or covered, so it is not easy to realize its existence. Power in its existence can only be felt from its effects. This power proposed by Foucault, according to K. Bertens, does not work through oppression and power in a physical sense, but it is exercised by strengthening regulations that are carried out and obeyed voluntarily in society.(K. Bertens, 2001, 321-322)

As explained earlier, knowledge referred to by Foucault is different from discourse, but the two are related. For him, knowledge is a discourse that operates in a network of power. This power does not appear but works within the organization's own system. According to K. Bertens, Foucault's assumptions position knowledge as something that is not neutral in nature, but is political in nature.(K. Bertens, 2001, 320-321) Through knowledge, activities and life are regulated by certain regulations. In the context of the state, both knowledge and discourse can be used to regulate, direct and condition the running of the state in accordance with certain political objectives. In the field of education, in the Old or New Order Era, power proved to play an important role in the formation of knowledge and discourse that benefited schools in public perception. While in the reform era, power seems to favor the pesantren, especially after the passing of the Pesantren Bill and a Santri Day. (DetikNews, 2019; Kompas.com, 2015).

The reality about schools, pesantrens or madrasas is in fact very likely to be formed and produced through a variety of knowledge and discourses that support each other. These discourses in the logic of Foucault's theory become a public knowledge that is consumed by the public including their regulations. The construct of these discourses is what limits our perspective or perception of something, so that general knowledge disseminated in various aspects of complementary knowledge can illustrate the reality accepted by the public.(Michel Foucault, 1976, 74)

Based on Foucault's theoretical assumptions about knowledge, power and discourse, the performance of madrasas, which until today is still relatively low and unable to compete with public schools or pesantren, can be determined by several factors, namely: first, the "blueprint" for the fortering and development of madrasas which is not yet firmly established, inversely proportional to schools or pesantren; second, the issue of interplay of madrasa policies in the integration of the national education system which is in the middle of the dominance of schools and pesantren; and third, the tendency of a low level of community 
appreciation for participating in madrasa development because the public compares with the quality of schools and pesantren.

\section{Conclusion}

In Indonesia, the madrasa emerged from progressive ideas that responded to pesantren attitudes that avoided modernization. However, in its development, the madrasa actually experienced a setback trend. In this respect, the development of madrasa is closely related to what Michel Foucault called power, knowledge and discourse. Madrasa performance which until today is still relatively low and unable to compete with public schools or pesantren, can be identified from this perspective.

Foucault argues that the power produces reality, scope, objects, and rites of truth. Power goes through normalization and regulation. Normalization is produced by creating a structured and systematic control system with regulations. Foucault explained the relationship between power and knowledge. According to him, power and knowledge have a very close and inseparable relationship. Power produces knowledge, whereas knowledge has power. Power in the Foucault's definition is disguised, hidden and/or covered, so it is not easy to realize its existence. Power in its existence can only be felt from its effects. This power is carried out by strengthening regulations that are implemented and obeyed voluntarily in society.

Knowledge referred to by Foucault is different from discourse, but the two are related. For him, knowledge is a discourse that operates in a network of power. This power does not appear but works within the organization's own system. According to him, knowledge is not neutral, but political. So the reality about madrasas is very possible to be formed and produced through a variety of knowledge and discourses that support each other based on the state's wishes. These discourses in the logic of Foucault's theory become a public knowledge that is consumed by the public, which then limits the perspective or perception of the public about madrasas.

As understood, the "blueprint" for the fostering and development of madrasas is not yet well established, inversely proportional to schools or pesantren. Likewise, the emergence of problems of madrasa policy interplay in the integration of the national education system has made madrasas stuck in between the school and pesantren dominance. Additionally in society, there is a tendency for low appreciation and level of community participation in madrasas. A lot of opinions that arise among the public perceive madrasas as second-class educational institutions and are less qualified when compared to the quality of schools or pesantren. 
This opinion is evidently supported by empirical research data. An empirical example of the poor quality is the madrasas in the outermost, interior and underdeveloped areas of Indonesia. For example, a study conducted by Nur Hamzah (2017) on unaccredited madrasas in the interior of Kubu Raya in West Kalimantan Province provides a portrait of the poor quality of our madrasas today, especially in the areas mentioned above, where the facilities and infrastructure are inadequate, the educational qualifications of teachers and the quality of education are both low. Similar case was also reported by Sukino (2017) based on his research.

\section{REFERENCES}

Abuddin Nata. (2012). Manajemen Pendidikan : Mengatasi Kelemahan Pendidikan Islam di Indonesia. Jakarta: Kencana Prenada Media Group.

Agus Salim. (2015). Madrasah dan Globalisasi. Tajdid : Jurnal Ilmu Ushuluddin, 14(1), 63-94. https://doi.org/10.30631/tjd.v14i1.23

Ahmad Syalabi. (1973). Sejarah Pendidikan Islam. Jakarta: Bulan Bintang.

Ainurrofiq Dawam, \& Ahmad Ta'arifin. (2005). Manajemen Madrasah Berbasis Pesantren. Jakarta: Listafariska Putra.

Ara Hidayat, \& Imam Machali. (2012). Pengelolaan Pendidikan (Konsep, Prinsip, dan Aplikasi dalam Mengelolah Sekolah dan Madrasah. Yogyakarta: Kaukaba.

DetikNews. (2019, 24 September). 5 Poin RUU Pesantren yang Disahkan DPR Hari Ini. Detik News. https://news.detik.com/berita/d-4720447/5-poin-ruu-pesantren-yang-disahkandpr-hari-ini

H. Mahmud Yunus. (1986). Sejarah Pendidikan Islam. Jakarta: Hidakarya Agung.

Hamruni, \& Syamsul Kurniawan. (2018). Political Education of Madrasa in the Historical Perspective. Sunan Kalijaga International Journal on Islamic Education Research (SKIJIER), 2(2), 139-156.

Husni Rahim. (2005). Madrasah dalam Politik Pendidikan di Indonesia. Jakarta: Logos.

Ibnu Rusydi. (2014). Optimisme Pendidikan Madrasah Di Indonesia: Prospek dan Tantangan. Risâlah, Jurnal Pendidikan dan Studi Islam, 1(1).

Jamal Makmur Asmani. (2013). Kiat Melahirkan Madrasah Unggulan: Merintis dan Mengelola Madrasah yang Kompetitif. Yogyakarta: Diva Press.

K. Bertens. (2001). Filsafat Barat Kontemporer. Jakarta: Gramedia.

Karel A. Steenbrink. (1994). Pesantren Madrasah Sekolah : Pendidikan Islam dalam Kurun Moderen. Jakarta: LP3ES. 
Kementerian Agama. (2005). Desain Pengembangan Madrasah. Jakarta: Direktorat Jendral Kelembagaan Agama Islam.

Kementerian Pendidikan dan Kebudayaan. (2018). Rekap Hasil Ujian Nasional (UN). https://puspendik.kemdikbud.go.id/hasil-un/

Ki Supriyoko. (2004). Masa Depan Madrasah di Indonesia. Media Indonesia.

Kompas.com. (2015, 15 Oktober). Jokowi Tanda Tangani Keppres 22 Oktober Jadi Hari Santri.

Kompas.com.

https://nasional.kompas.com/read/2015/10/15/16195371/Jokowi.Tanda.Tangani.Ke ppres.22.Oktober.Jadi.Hari.Santri

M. Daud Yahya. (2014). Posisi Madrasah dalam Sistem Pendidikan Nasional di Era Otonomi Daerah. Khazanah, 12(1).

Mahmud Yunus. (1979). Sejarah Pendidikan Islam di Indonesia. Jakarta: Mutiara.

Maksum. (1999). Madrasah: Sejarah dan perkembangannya (Cet. 1). Ciputat, [Jakarta]: Logos Wacana Ilmu.

Masyhuri dan Taufiq Dahlan. (2006). Perencanaan dan Pengembangan Madrasah. Jakarta: Departemen Agama RI, Majelis Pertimbangan dan Pemberdayaan Pendidikan Agama dan Keagamaan.

Mehdi Nakosteen. (1964). History of Islamic Origins of Western Education. US: Ibex Publications.

Michel Foucault. (1976). The archaeology of knowledge. New York: Harper \& Row.

Michel Foucault. (1980). Power/knowledge : Selected interviews and other writings, 19721977. New York: Pantheon Books.

Moh. Arif. (2013). Manajemen Madrasah dalam Upaya Peningkatan Mutu Pendidikan Islam. Episteme, 8(2), 415-438.

Muhaimin. (2003). Wacana Pengembangan Pendidikan Islam. Yogyakarta: Pustaka Pelajar \& Pusat Studi Agama, Politik dan Masyarakat.

Muhammad Kosim. (2017). Madrasah di Indonesia (Pertumbuhan dan Perkembangan). Tadris, 2(1), 41-57.

Mukminin Gaffar. (2012). Manajemen Pendidikan Madrasah dan Otonomi Daerah. Sulesana, $7(2), 128-137$.

Muzhoffar Akhwan. (2008). Pengembangan Madrasah sebagai Pendidikan untuk Semua, $1(1)$.

Novita Intan. (2018, 15 Maret). Masih Banyak Madrasah yang Kondisinya Memprihatinkan. Republika. https://www.republika.co.id/berita/dunia-islam/islam- 
nusantara/18/03/15/p5mojs313-masih-banyak-madrasa-yang-kondisinyamemprihatinkan

Nur Hamzah. (2017). Wajah Buram Madrasah Indonesia (Studi Pada Beberapa Madrasa Tidak Terakreditasi di Pedalaman Kubu Raya). At-Turats, 11(2), 105-112. https://doi.org/10.24260/at-turats.v11i2.895.g484

Republic of Indonesia Law Number 20 of 2003 concerning the National Education System. (2003). Jakarta: Indonesian Ministry of National Education.

Stanton, C. M. (1990). Higher learning in Islam : The classical period, A.D. 700-1300. Savage, Md: Rowman \& Littlefield.

Sukino. (2017). Pengembangan Kurikulum Madrasah di Daerah Transisi. Tarbawi, 3(1), 24-42. http://dx.doi.org/10.32678/tarbawi.v3i01.1777

Supani. (2009). Sejarah Perkembangan Madrasah di Indonesia. INSANIA, 14(3), 1-14.

Suyatno. (2012). Dekonstruksi Pendidikan Islam Sebagai Subsistem Pendidikan Nasional. Jurnal Pendidikan Islam, 1(1), 121-138.

Syamsul Kurniawan. (2017). Gagasan pendidikan kebangsaan Soekarno : Ide progresif atas pendidikan Islam Indonesia. Malang: Madani.

Syamsul Kurniawan. (2018). Sukarno's Thought on the Importance of Reintegration of Religion and Science in Pesantren Education in Indonesia. Journal of Indonesian Islam, 12(2), 219. https://doi.org/10.15642/JIIS.2018.12.2.219-246

Syamsul Kurniawan. (2019). Tantangan Abad 21 bagi Madrasah di Indonesia. Intizar, 25(1), 55-68. https://doi.org/10.19109/intizar.v25i1.3242

Tabrani ZA. (2013). Kebijakan Pemerintah Dalam Pengelolaan Satuan Pendidikan Keagamaan Islam: Tantangan Terhadap Implementasi Manajemen Berbasis Sekolah. Serambi Tarbawi, 1(2).

Weti Susanti. (2017). Pembinaan dan Pengembangan Madrasah Sampai Masa Sekarang. Jurnal Pendidikan Islam, 1(1), 1-19. 